\title{
Syndromes that Include both Palmoplantar Keratoderma and Severe
} Periodontitis: a Review

\section{Dababneh $\mathbf{R H}^{1}$, Bissada NF${ }^{2 *}$}

${ }^{1}$ Department of Periodontics, King Hussein Medical Center, Royal Medical Services, Amman, Jordan

${ }^{2}$ Department of Periodontics, School of Dental Medicine, Case Western Reserve University, Cleveland, OH, USA

\begin{abstract}
Palmoplantar keratodermas (PPK) include a heterogeneous group of disorders with overlapping clinical features. The main aspect of PPK is thickening and hyperkeratosis of the palmar and plantar skin, that may be hereditary or acquired; diffuse, focal, or punctuate; and transgrediens or progrediens. PPKs are further distinguished by their mode of inheritance and by the presence of certain associated clinical features. Periodontitis was reported in association with more than one syndrome characterized by PPK. An extensively reported one is the Papillon-Lefévre syndrome (PLS) which is characterized by early onset of PPK and periodontitis affecting the primary and secondary dentitions. In addition to PLS, Haim-Munk, HOPP, Variant Carvajal and Weary-Kindler are other syndromes manifested by PPK and reported in association with severe periodontitis. Atypical cases of PLS were also reported, such as partial expression or a late presentation of the syndrome. The aim of this article is to critically review the literature concerned with Papillon-Lefévre syndrome in its typical and atypical clinical presentation, in addition to other syndromes manifested at the same time by PPK and severe periodontitis.
\end{abstract}

Thorough history and medical examination, together with periodontal, dermatologic, and genetic counseling, are important to exclude other existing medical conditions or other syndromes that might need special attention and care.

Keywords: Papillon-Lefevre syndrome; Palmoplantar keratoderma; Aggressive periodontitis

\section{Introduction}

Periodontal disease is a spectrum of different diseases for which certain individuals are at relatively high risk [1]. Periodontitis is defined as a bacterial disease resulting in inflammation within the supporting tissues of the teeth, progressive attachment and bone loss [2]. Epidemiologic surveys in young individuals have been performed in many parts of the world and among individuals with a widely varied background. For the most part, these surveys indicated that the prevalence of severe attachment loss on multiple teeth among children and young adults are limited. The United States national survey of 11,000 children aged 14-17 years showed that the prevalence of periodontitis was approximately $0.2 \%$ to $0.5 \%$ [3]. Periodontitis among young individuals is significantly more common in developing than in developed countries, with a significant difference among races and ethnic groups [4].

The nomenclature and classification systems used to describe periodontal disease have changed periodically over the past decades [58]. Prepubertal periodontitis is a rare early-onset form of periodontitis that was first described by Page et al. as a distinct clinical entity. It begins with the eruption of the primary teeth and presents in a localized or generalized form. Generalized prepubertal periodontitis (GPP) affects all primary and secondary dentition and is characterized by severe gingival inflammation, rapid destruction of the soft and hard periodontal tissues, mobility, and premature tooth loss [9]. The International Workshop for a Classification of Periodontal Diseases and Conditions held in 1999 established a new classification. According to this classification, the term "prepubertal periodontitis", in particular the generalized form is replaced with the more recent term "periodontitis as a manifestation of systemic diseases" [8]. Systemic disorders that might present as periodontitis were divided into three categories: 1) those associated with acquired hematological disorders such as neutropenia and leukemias; 2) those associated with genetic disorders such as familial and cyclic neutropenia, Down syndrome, leukocyte adhesion deficiency syndromes, Papillon-Lefévre syndrome, ChediakHigashi syndrome, Ehlers-Danlos syndrome (Types IV and VIII), hypophosphatasia, and others [8,9]; and 3) disorders not otherwise specified.

Palmoplantar keratodermas (PPKs) is a heterogeneous group of disorders characterized by thickening or hyperkeratosis of the palmar and plantar skin with or without other associated clinical features. The underlying gene defects for many types of hereditary PPKs have been defined. The involved genes encode intracellular structural proteins, desmosomal proteins, gap junction components, and enzymes [10]. PPKs are classified as hereditary or acquired; diffuse, focal or punctuate; and transgrediens or progrediens. Hereditary type follows autosomal recessive or dominant patterns [11]. Acquired PPKs maybe a result of internal disease, drug-related, malnutrition-associated, chemicallyinduced, systemic disease-related, malignancy-associated, dermatosesrelated, infectious, or idiopathic [12]. Punctuate and focal types of PPK affect localized areas of the palms and soles, whereas the diffuse type affects most of the palms and soles. The latter type is further subdivided into: type I, or classical Vörner type which consists of epidermolytic PPK; type II, or Unna-Thost type, consists of non-epidermolytic PPK; type III, in which the hyperkeratotic plaques are not confined exclusively to the palms and soles, but comprises such entities of erythrokeratodermas Mendes da Costa or keratosis palmoplantaris transgrediens and progrediens, Greither's type (progressive diffuse PPK with hyperhidrosis); and type IV, the palmoplantar ectodermal keratoderm as associated with periodontitis [13]. It is the early onset of periodontal disease component that distinguishes these from the other more common forms of PPK. Therefore, PPKs are further distinguished by the presence of associated features. For example keratoderma may be limited to the volar surface of the palms of the hands and soles of the feet, i.e., transgrediens, or extends onto the dorsal aspect as well, i.e., progrediens [14].

*Corresponding author: Dr. Nabil F. Bissada, DDS, MSD, School of Dental Medicine, Case Western Reserve University, 10900 Euclid Avenue, Cleveland Ohio 44106-4905, USA, Tel: (216) 368-6752; Fax: (216) 368-3204; E-mail: nabil.bissada@case.edu

Received November 27, 2013; Accepted December 26, 2013; Published December 28, 2013

Citation: Dababneh RH, Bissada NF (2013) Syndromes that Include both Palmoplantar Keratoderma and Severe Periodontitis: a Review. Dentistry 4: 186 doi:10.4172/2161-1122.1000186

Copyright: $\odot 2013$ Dababneh $\mathrm{RH}$, et al. This is an open-access article distributed under the terms of the Creative Commons Attribution License, which permits unrestricted use, distribution, and reproduction in any medium, provided the original author and source are credited. 


\section{Papillon-Lefévre Syndrome}

Papillon-Lefévre syndrome (PLS) is defined as periodontitis associated with type IV diffuse palmoplantar ectodermal keratodermas. It was first described by two French dermatologists Papillon and Lefévre in 1924 as "Mal de Meleda" which is characterized by diffuse PPK with disseminated keratotic lesions, in particular on the elbows and knees [15]. PLS, however, is typically associated with premature loss of deciduous and permanent teeth and severe periodontitis which develops shortly after tooth eruption and subsides after exfoliation of the teeth [16]. Consanguinity between parents is a factor in a significant number of PLS cases [17]. No gender or racial predominance was reported for PLS [16]. More recently, PLS is recognized as a rare autosomal recessive disorder caused by mutations in Cathepsin $\mathrm{C}$ gene. The exact etiology and pathogenesis of this syndrome are still not fully understood. Several factors were attributed to the etiology of PLS-periodontitis including microbiologic, immunologic, and genetic. Gram-negative anaerobic rods were predominantly found in PLS periodontitis lesions [18]. Aggregatibacter actinomycetemcomitans was also reported to have a significant role in the pathogenesis and progression of periodontal involvements in PLS patients. Several patients, however, were positive for other periodontal pathogens [19-21]. PLS-periodontitis was also reported to be associated with human herpesviruses [22].

Dysfunction of polymorphonuclear leukocytes (PMNs) is found to play a role in the etiology of PLS-periodontitis. PMNs released significantly increased amounts of $\mathrm{O}_{2}$ in PLS patients compared to controls [23]. PMNs chemotaxis, phagocytosis of opsonized Staphylococcus aureus, and production of superoxide radicals by PMNs are significantly impaired in PLS patients [24]. These functionally defective PMNs are reported to be inheritable, thus leading to difficulty in coping with periodontitis-associated pathogens $[25,26]$.

Ultrastructural examination of the periodontal lesion in PLS revealed primary defects of cementum or periodontal ligament attachment, and disruption of fibroblast and cementoblast function [27]. Low salivary secretion rate, peroxidase level and buffering capacity are also other reported findings in PLS patients [28].

A gene defect responsible for PPK and periodontitis is thought to be caused by a defect in keratin gene clusters. However, Hart et al. in 1997 suggested that mutations in other genes are the cause [29]. In the same year, the PLS gene was demonstrated to be localized to chromosome 11q14 by homozygosity mapping [17,30]. Later it was found that PLS is caused by mutations in the gene encoding Cathepsin $\mathrm{C}$, a lysosomal cysteine protease of the papain type known as dipeptidyl aminopeptidase (CTSC and DPP1) [31,32]. However, some CTSC mutations are causal for prepubertal periodontitis without PPK, and no relationship has been shown between CTSC mutations and other forms of periodontitis [33]. According to the Human Gene Mutation Database (HGMD), 77 variants of the CTSC gene exist [34].

\section{Typical Features of Papillon-Lefévre Syndrome}

The two main clinical features of PLS are early onset of palmoplantar keratoderma and severe periodontitis of the primary and permanent dentitions. Dermatological disorders in PLS are manifested with erythema, which progresses within six months to hyperkeratosis of soles, palms, knees, and elbows [35]. The manifestations in the palms and soles vary from mild psoriasi form scaly skin to overt hyperkeratosis that typically develops within the first three years of life. Keratosis may also affect other sites such as the elbows and knees [31]. Although there is a significant correlation between the severities of keratosis in the feet and hands, changes in the feet are more severe [36]. There also is a positive correlation between the severity of skin lesions and seasonal variations as well as intensified periodontal destruction [37]. Other skin areas involved manifestations of PLS include eyelids, cheeks, thighs, and external malleolus [38].

In PLS aggressive periodontal destruction begins with the primary dentition, leading to premature loss of deciduous teeth by age 6 years; until the eruption of the permanent dentition, where periodontitis reappears and the teeth are prematurely lost by the age of 16-years $[35,39]$. Ullbro et al. analyzed 47 patients with PLS and found, with no exception, that both skin and oral changes developed early in life in all the patients studied. Dermatologic involvement showed no correlation with age, whereas periodontal disease was significantly worse in young children with deciduous teeth [36]. No significant correlation, however, was demonstrated between the severity of the periodontal and of skin affections [36]. There was an early eruption of the permanent teeth, which were caries-free with no sign of root resorption [37].

\section{Secondary Features associated with PLS}

In addition to palmoplantar keratoderma and early periodontal destruction of primary and permanent dentition, other features may be associated with PLS, i.e., increased susceptibility to infection [16], increased risk of pyogenic liver abscess [40-43], calcification of the falx cerebri of the dura mater [44], excessive sweating (hyperhidrosis), and growth of fine body hair with the development of dirty-colored skin on the affected areas [45]. Recently, the first case of multiple brain abscesses in a child with PLS was reported [46]. The association between pyogenic liver abscess and PLS may be related to neutrophil dysfunction [41]. PLS was also reported to be associated with type-1 oculocutaneous albinism (OCA). Seven cases (six males and one female) from Egypt and Jordan were described. All of the affected individuals exhibited the typical clinical features of PLS andtype-1 OCA, in addition to increased susceptibility to infection [47-50]. The co-occurrence of these two rare recessive genetic conditions was investigated by Hewitt et al. who concluded that the causative genes (CTSC and tyrosinase, respectively) shared their chromosomal location (11q14.2-14.3), but not their pathogenic mechanism $[48,49]$.

PLS was reported to be associated with pseudoainhum of the toes, i.e., formation of constricting bands around the fingers leading to autoamputation [51]. Mental retardation is another feature that is reported [38,52]. Xanthogranulomatous pyelonephritis, which is a rare, serious, chronic inflammatory disorder of the kidney characterized by a destructive mass that invades the renal parenchyma, has also been reported in a patient with PLS [53]. A patient with PLS associated with acroosteolysis and bone loss of the fingers and the toes was described for the first time [54]. Dystrophy and transverse grooving of the nails are another feature reported in PLS patients [55].

\section{Atypical PLS}

The term "syndrome" is derived from the Greek syn (together) and dromos (running) and refers to a running together or concurrence of symptoms. Its use for a single symptom or sign is incorrect [56]. However, a number of atypical PLS cases had been reported, including those with late presentation or partial expression of the syndrome, milder form of periodontitis or mild dermatological features. These features increase the ambiguity in understanding this syndrome and cause more confusion for the clinician to diagnose PLS-periodontitis.

Two atypical cases of familial Papillon-Lefévre syndrome were reported, one of which had only late onset of mild skin lesion, the other had severe skin lesions and relatively mild periodontal disease [57] 


\begin{tabular}{|c|c|c|c|c|c|}
\hline \multicolumn{6}{|c|}{ Main clinical features } \\
\hline Syndrome & $\begin{array}{c}\text { \# patients \& county } \\
\text { of origin }\end{array}$ & Dermal & Periodontal & Other & Comments \\
\hline Haim-Munk [67] & $\begin{array}{l}18 \text { cases from India } \\
1 \text { case from Brazil } \\
1 \text { case from Turkey }\end{array}$ & PPK & $\begin{array}{c}\text { Early onset periodontitis affecting } \\
\text { deciduous and permanent } \\
\text { dentitions }\end{array}$ & $\begin{array}{l}\text { Onychogryphosis } \\
\text { Acroosteolysis } \\
\text { Pesplanus } \\
\text { Heat intolerance } \\
\text { Lever abscess }\end{array}$ & $\begin{array}{c}\text { Autosomal recessive } \\
\text { inheritance } \\
\text { Causative gene CTSC } \\
\text { Variant of PLS or distinct } \\
\text { clinical entity }\end{array}$ \\
\hline PLS/H.M? [70] & $\begin{array}{l}2 \text { sisters from } \\
\text { Jordan }\end{array}$ & $\begin{array}{l}\text { PPK hyper- keratosis } \\
\text { of knees and elbows } \\
\text { Psoriasiform lesion } \\
\text { around the lips }\end{array}$ & $\begin{array}{l}\text { Early onset periodontitis affecting } \\
\text { both dentitions }\end{array}$ & $\begin{array}{c}\text { Onychogryphosis } \\
\text { Acroosteolysis } \\
\text { Pesplanus Bilateral distal } \\
\text { interphalangeal joint contracture }\end{array}$ & $\begin{array}{l}\text { Uncertain diagnosis } \\
\text { No genetic testing }\end{array}$ \\
\hline *HOPP $[72,73]$ & $\begin{array}{c}\text { Dutch mother } \\
\text { and daughter } \\
\text { Venezuelan male }\end{array}$ & $\begin{array}{l}\text { Striate palmoplantar } \\
\text { keratoderma }\end{array}$ & Periodontitis & $\begin{array}{c}\text { Hypotrichosis, Onychogryphosis, } \\
\text { Acro-osteolysis, Lingua plicata, } \\
\text { Psoriasis }\end{array}$ & $\begin{array}{l}\text { Mode of inheritance is } \\
\text { uncertain }\end{array}$ \\
\hline $\begin{array}{c}\text { Weary-Kindler } \\
{[74-76]}\end{array}$ & $\begin{array}{l}1 \text { case from } \\
\text { Afghanistan }\end{array}$ & PPK & $\begin{array}{c}\text { Early onset periodontitis of primary } \\
\text { and part of permanent dentitions } \\
\text { Gingival fragility }\end{array}$ & $\begin{array}{c}\text { Congenital poikiloderma } \\
\text { Epidermolysis } \\
\text { Bullosa } \\
\text { Photosensitivity }\end{array}$ & $\begin{array}{l}\text { Short-term favorable } \\
\text { response to periodontal } \\
\text { therapy }\end{array}$ \\
\hline $\begin{array}{c}\text { Variant } \\
\text { Carvajal [77] }\end{array}$ & $\begin{array}{l}\text { one female } \\
\text { from England }\end{array}$ & $\begin{array}{l}\text { Liner palmar and } \\
\text { diffuse plantar } \\
\text { keratoderma with } \\
\text { episodic plantar } \\
\text { fissures }\end{array}$ & $\begin{array}{l}\text { Prepubertal periodontitis, } \\
\text { Premature root resoption of } \\
\text { primary teeth } \\
\text { Missing permanent teeth, enamel } \\
\text { defects }\end{array}$ & $\begin{array}{l}\text { Wiry hair, } \\
\text { Abnormal finger nails } \\
\text { Cardiomyopathy }\end{array}$ & $\begin{array}{c}\text { Potential risk for cardiac } \\
\text { abnormalities }\end{array}$ \\
\hline
\end{tabular}

* Hypotrichosis, Acro-Osteolysis, Palmoplantarkeratoderma, Peridontitissyndrome.

Table 1: Summary of reported Syndromes manifested by Palmoplantar Keratoderma (PPK) and Periodontitis other than Papillon-Lefévre(PLS).

Partial and late presentation of PLS also were reported within the same family in which only late involvement of the permanent dentition with periodontitis in two daughters who showed periodontal breakdown and hyperkeratotic skin lesions. The deciduous dentition however, was not affected, although their two brothers have partial expression of the syndrome manifested only by skin lesions [24].

Partial expression of PLS was also reported in two families with several affected members of each family; they are from distantly separated areas in India and Germany. In each family, one individual has hyperkeratotic lesions with complete absence of periodontal lesions. Further, the difference in severity of the hyperkeratotic lesions between the two families is clear. One sibling in the German family expressed rapid, early onset periodontitis in the absence of PPK [58]

Kothiwale and Mathur in 2008 reported a different case of partial expression of PLS for a 35 year-old male with early onset PPK, but the eruption and exfoliation of the deciduous dentition was normal along with normal eruption of the permanent teeth. The periodontium is relatively healthy, with the exception of presence of moderate localized periodontal pockets [59]. The diagnosis of PLS in this case is questionable. In contrast, Kamalpreet et al. reported a late presentation of PLS in a 20-year-old female with marked early onset PPK but with a history of normal eruption and exfoliation of the primary teeth and normal eruption of permanent dentition. When the patient reached 19 years, she noticed mobility and migration of teeth, family history indicated that her mother had lost all her teeth at a young age and one of her sisters had severe periodontal disease but no history of hyperkeratosis [60]. In our opinion, this is a case of PPK associated with aggressive periodontitis with a family history of severe periodontitis.

Another case of PLS in association with aggressive periodontitisof a 28-year old male with PPK was reported by Reenesh et al. [61] In this case, no genetic analysis was performed. The authors reported a successful outcome with oral retinoid and periodontal therapy including surgical and non-surgical therapy with antibiotics [61]. Because the authors reported the restoration of the periodontium to a healthy status with conventional periodontal therapy, we question whether this case is a true PLS, or a rapidly progressive form of periodontitis.
A more clear illustration of these different cases was reported by Fardal et al. as "PPK and unusual periodontal findings in a family" where the father has marked PPK and very late onset of destructive periodontitis. The son also has palmoplantar hyperkeratosis, and did not develop periodontal disease over a seven-year observation period after improved oral hygiene and professional tooth cleaning were instituted [62]. Pilger et al. also reported a46-year-old woman with late-onset PPK and a 10-year history of severe periodontal disease. There was no mutation in the cathepsin $\mathrm{C}$ gene. The authors suspect a different genetic cause responsible for this late-onset forms of PLS [63]. In some cases, the reason for considering late presentation of PLS is not clear as in the case of a 25-year-old Iranian edentulous woman who presented originally at 7 years of age with PPK and started to lose her permanent teeth at the age of 12 years [42]. Kobayashi et al., however, explained the late presentation of PLS periodontitis with atypical clinical feature of retention of all the permanent teeth at over 40 years of age by identifying a novel CTSC homozygous nonsense mutation, p.Lys106X, which leads to a deficiency of the mutant mRNA because of nonsense-mediated mRNA decay [64]. Therefore, the phenotypic variability of the PLS associated with identical genetic background may reflect the influence of additional genetic and/or environmental factors on disease characteristics [65].

\section{Other Syndromes Reported PPK in Association with Periodontitis (Table 1)}

\section{Haim and munk syndrome}

Haim and Munk reported findings similar to Papillion-Lefevre syndrome in four sibs of a Jewish religious isolate from Cochin, India, on the Malabar Coast who later migrated to Israel [66]. Hence, the name Haim-Munk syndrome (HMS) was introduced. Since then, it is considered by some clinicians as a variant of PLS $[35,67,68]$. However, other clinicians distinguished HMS as a separate disorder owing to the presence of additional features different from PLS [29]. Features that are similar in both PL and H.M syndromes include palmoplantar keratosis and progressive early onset periodontal destruction. There are, however, a number of additional features in HMS that include arachnodactyly (long, thin, pointed fingers); acroosteolysis (bone loss in the fingers or 
toes); onychogryphosis (overgrowth of the fingernails and toenails and a claw-like deformity); Pesplanus (flat foot), and psoriasiform lesions. Two Jordanian girls with symptoms similar to Haim-Munk syndrome were recently documented [69]. Shah et al. pointed out the need to differentiate PLS from other diseases that show severe periodontitis and dermatological lesions, like Haim Munk syndrome [70].

A combination of findings that are not previously reported including congenital atrichia and mental retardation in addition to palmoplantar hyperkeratosis and early loss of teeth was documented in four siblings, and considered to be a new genetic entity [71].

\section{Hypotrichosis, Acro-Osteolysis, Palmoplantar keratoderma and Peridontitis Syndrome (HOPP)}

This syndrome was first reported in a Dutch mother and daughter. The PPK followed a highly unusual reticular pattern and both the mother and daughter have a lingua plicata (fissured tongue). This new syndrome is not related to mutations in cathepsin $C$ gene [72]. A third, unrelated, 24-year-old patient from Venezuela suffering from what appears to be HOPP syndrome confirms the existence of this syndrome as a unique entity and further delineates the phenotype [73].

\section{Weary-Kindler and kindler syndromes}

These are two different syndromes, but sharing similar features [74]. Kindler syndrome is an autosomal recessive disorder characterized by epidermolysis bullosa, congenital poikiloderma, PPK, photosensitivity, skin atrophy, and mucosal lesions [75] whereas Weary-Kindler syndrome is a dominantly inherited disorder with features similar to those reported in the Kindler syndrome except for skin atrophy, photosensitivity, and mucosal lesions [76].

\section{Variant carvajal syndrome}

This syndrome was reported in a 13-years old girl who had been under long term dental care for prepubertal periodontitis, premature root resorption of primary teeth, soft tissue and dental anomalies, and angular cheilitis [77].

\section{Conclusion}

1. PPK as well as periodontitis include many types. Genetic syndromes may be manifested by PPK or by periodontitis, but Papillon-Lefévre syndrome is the most recognized syndrome sharing these two features.

2. Although the exact etiology, pathogenesis and clinical manifestation are not clearly understood in the many cases of atypical PLS that have been reported, the genetic etiology is properly identified to Cathepsin C (CTSC) gene on chromosome 11q14.Genetic testing therefore, may be used to confirm the diagnosis of this syndrome.

3. Typical types of PLS include: 1) the two features of PPK and periodontitis; 2) early onset of both skin and oral changes during the first three years of life, 3 ) both the deciduous and permanent dentitions are affected and the patient looses the permanent teeth by the teen age; 4) calcification of the falx cerebri of the dura mater; and 5) development of pyogenic liver abscess are additional specific associated features.

4. Atypical PLS cases include partial expression of the syndrome (PPK or periodontitis); or late presentation instead of early onset, or periodontitis affecting only the permanent dentition; or associated with additional features such as pseudoainhum of the fingers and toes.
5. The establishment of definitive diagnosis for PLS or PLSperiodontitis seems uncertain in cases of atypical presentation, especially without genetic testing. In case of doubtful diagnosis, "PPK associated with aggressive or chronic periodontitis", instead of "late presentation of PLS" is more appropriate at the present time.

6. The term "partial expression of PLS" seems inappropriate for a syndrome that is manifested by no more than two features, i.e., PPK and periodontitis.

7. Most of the periodontal findings appeared in the literature are not described in detail. Genetic testing also is unrecorded.

8. For better understanding and management of patients with PLS, a team of specialists in dermatology, periodontics, and genetics is necessary to rule out the possibility of other medical conditions.

\section{References}

1. Johnson NW, Griffiths GS, Wilton JMA Maiden MFJ, Curtis MA et al. (1988) Detection of high-risk groups and individuals for periodontal diseases. Evidence for the existence of high-risk groups and individuals and approaches to their detection. J Clin Periodontol 15: 276-282.

2. The American Academy of Periodontology (2001) Glossary of periodontal terms. (4thedn), Chicago.

3. Löe H, Brown LJ (1991) Early onset periodontitis in the United States of America. J Periodontol 62: 608-616.

4. Albandar JM, Tinoco EMB (2002) Global epidemiology of periodontal diseases in children and young persons. Periodontology 29: 153-176.

5. Suzuki JB (1988) Diagnosis and classification of the periodontal diseases. Dent Clin North Am 32: 195-216.

6. Ranney RR (1993) Classification of periodontal diseases. Periodontology 2 : $13-25$

7. Armitage GC (1996) Periodontal diseases: Diagnosis. Ann Periodontol 1: 215 237.

8. Armitage GC (1999) Development of a classification system for periodontal diseases and conditions. Ann Periodontol 4: 1-6.

9. Dababneh R, Al-wahadneh AM, Hamadneh S, Khouri A, Bissada NF (2008) Periodontal Manifestation of Leukocyte Adhesion Deficiency Type I. J Periodontol 79: 764-768.

10. Kimyai-Asadi A, Kotcher LB, Jih MH (2002) The molecular basis of hereditary palmoplantar keratodermas. J Am Acad Dermatol 47: 327-343.

11. Sam H, Sasseville D (2003) The Hereditary Palmoplantar Keratodermas Dermatology Rounds.

12. Patel S, Zirwas M, English JC $3^{\text {rd }}(2007)$ Acquired palmoplantar keratoderma. Am J Clin Dermatol 8: 1-11.

13. Stevens HP, Kelsell DP, Bryant SP, Bishop DT, Spurr NK, et al. (1996) Linkage of an American pedigree with palmoplantar keratoderma and malignancy (palmoplantar ectodermal dysplasia type III) to 17q24. Literature survey and proposed updated classification of the keratodermas. Arch Dermatol 132: 640651.

14. Krol AL, Jorizzo JL, Rapini (2003) Keratodermas. (1stedn), Mosby, Toronto.

15. Papillon MM, Lefe'vre $P$ (1924) cas de keratodermiepalmaire et plantairesymmetriquefamiale (maladie de Meleda) chez le fre re et la soeur: coe'xistancedans les deuxcasd'alte'rationsdentaires graves. Bull Soc Derma Symp 31: 82-87.

16. Haneke E (1979) The Papillon-Lefèvre syndrome: keratosis palmoplantaris with periodontopathy. Report of a case and review of the cases in the literature. Hum Genet 51: 1-35.

17. Laass MW, Hennies HC, Preis S, Stevens HP, Jung M, et al. (1997) Localisation of a gene for Papillon-Lefevre syndrome to chromosome 11q14-q21 by homozygosity mapping. Hum Genet 101: 376-382. 
Citation: Dababneh RH, Bissada NF (2013) Syndromes that Include both Palmoplantar Keratoderma and Severe Periodontitis: a Review. Dentistry 4: 186. doi:10.4172/2161-1122.1000186

18. Newman M, Angel I, Karge H, Weiner M, Grinenko V, et al. (1977) Bacterial Studies of the Papillon-Lefevre Syndrome. J Dent Res 56: 545.

19. Umeda M, Zhang YJ, Koseki T, Ishikawa I (1990) Clinical, bacteriological and immunological examination and treatment of two Papillon-Lefe vre syndrome patients. KokubyoGakkaiZasshi 57: 430-440.

20. Ishikawa I, Umeda M, Laosrisin N (1994) Clinical, bacteriological, and immunological examinations and the treatment process of two Papillon-Lefèvre syndrome patients. J Periodontol 65: 364-371.

21. Nickles K, Schacher B, Ratka-Krüger P, Krebs M, Eickholz P (2013) Longterm results after treatment of periodontitis in patients with Papillon-Lefèvre syndrome: success and failure. J Clin Periodontol 40: 789-798.

22. Velazco CH, Coelho C, Salazar F, Contreras A, Slots J, et al. (1999) Microbiological features of Papillon-Lefèvresyndrome periodontitis. J Clin Periodontol 26: 622-627.

23. Bimstein E, Lustmann J, Sela MN, Neriah ZB, Soskolne WA (1990) Periodontitis associated with Papillon-Lefèvre syndrome. J Periodontol 61: 373-377.

24. Bullon P, Pascual A, Fernandez-Novoa MC, Borobio MV, Muniain MA, et al (1993) Late onset Papillon-Lefèvre syndrome? A chromosomic, neutrophil function and microbiological study. J Clin Periodontol 9: 662-667.

25. deHaar SF, Hiemstra PS, van Steenbergen MTJM, Everts V, Beertsen W (2006) Role of Polymorphonuclear Leukocyte-Derived Serine Proteinases in Defense against Actinobacillusactinomycetemcomitans. Infect Immun 74: 5284-5291.

26. Meade JL, de Wynter EA, Brett P, Sharif SM, Woods CG, et al. (2006) A family with Papillon-Lefevre syndrome reveals a requirement for cathepsin $C$ in granzyme B activation and NK cell cytolytic activity. Blood 107: 3665-3668.

27. Vrahopoulos TP, Barber P, Liakoni H, Newman HN (1988) Ultrastructure of the periodontal lesion in a case of Papillon-Lefévre syndrome (PLS). J Clin Periodontol 15: 17-26.

28. Lundgren T, Crossner CG, Twetman S, Ullbro C (1996) Systemic retinoid medication and periodontal health in patients with Papillon-Lefevre syndrome. J Clin Periodontol 23: 176-179.

29. Hart TC, Stabholz A, Meyle J, Shapira L, Van Dyke TE, et al. (1997) Genetic studies of syndromes with severe periodontitis and palmoplantar hyperkeratosis. J Periodontal Res 32: 81-89.

30. Fischer J, Blanchet-Bardon C, Prud'homme JF, Pavek S, Steijlen PM, et al (1997) Mapping of Papillon-Lefevre syndrome to the chromosome 11q14 region. Europ J Hum Genet 5: 156-160.

31. Toomes C, James J, Wood AJ, Wu CL, McCormick D, et al. (1999) Loss-offunction mutations in the cathepsin $C$ gene result in periodontal disease and palmoplantar keratosis. Nat Genet 23: 421-424.

32. Hart TC, Hart PS, Bowden DW, Michalec MD, Callison SA, et al. (1999) Mutations of the cathepsin $C$ gene are responsible for Papillon-Lefévre syndrome. J Med Genet 36: 881-887.

33. Loos BG, John RP, Laine ML (2005) Identification of genetic risk factors for periodontitis and possible mechanisms of action. J Clin Periodontol 32: 159179.

34. Romero-Quintana JG, Frías-Castro LO, Arámbula-Meraz E, Aguilar-Medina M, Dueñas-Arias JE, et al. (2013) Identification of novel mutation in cathepsin C gene causing Papillon-Lefèvre Syndrome in Mexican patients. BMC Med Genet 14: 7-17.

35. Gorlin RJ, Pindborg JJ, Cohen MM (1976) Syndromes of the Head and Neck. (2ndedn), McGraw-Hill, New York.

36. Ullbro C, Crossner CG, Nederfors T, Alfadley A, Thestrup-Pedersen K (2003) Dermatologic and oral findings in a cohort of 47 patients with Papillon-Lefevre syndrome. J Am Acad Dermatol 48: 345-351.

37. Hattab FN, Rawashdeh MA, Yassin OM, Al-Momani AS, Al-Ubosi MM (1995) Papillon-Lefevre syndrome: a review of the literature and report of 4 cases. J. Periodontol 66: 413-420.

38. Valeshabad AK, Mazidi A, Valeshabad RK, Imani E, Kord H, et al. (2012) Papillon-Lefèvre Syndrome: A Series of Six Cases in the Same Family. ISRN Dermatol 139104.

39. Nazzaro V, Blanchet-Bardon C, Mimoz C, Revuz J, Puissant A (1988) PapillonLefévre syndrome - Ultrastructure study and successful treatment withacitretin. Arch Dermatol 124: 533-539.
40. Oğuzkurt P, Tanyel FC, Büyükpamukçu N, Hiçsönmez A (1996) Increased risk of pyogenic liver abscess in children with Papillon-Lefevre syndrome. J Pediat Surg 31: 955-956

41. Almuneef M, Al Khenaizan S, Al Ajaji S, Al-Anazi A (2003) Pyogenic liver abscess and Papillon-Lefèvre syndrome: not a rare association. Pediatrics 111 85-88

42. Yazdanfar A, Sasan F (2009) Late-onset Papillon-Lefevre syndrome with pyogenic liver abscesses: report of one case. Int J Dermatol 48: 76-78.

43. Das SK, Nath T, Ganguly P, Jana CK (2013) A rare case of recurrent pyogenic liver abscess since childhood: A case of Papillon-Lefèvre syndrome. Medical Journal of Dr. D.Y. Patil University 6: 86-88.

44. Gorlin RJ, Sedano H, Anderson VE (1964) The syndrome of palmar-plantar hyperkeratosis and premature periodontal destruction of teeth. A clinical and genetic analysis of the Papillon-Lefèvre syndrome. J Pediatr 65: 895-908.

45. Posteraro AF (1992) Papillon-Lefèvre syndrome. J Ala Dent Assoc 76: 16-19.

46. Kanthimathinathan HK, Browne F, Ramirez R, McKaig S, Debelle G, et al. (2013) Multiple cerebral abscesses in Papillon-Lefèvre syndrome. Childs Nerv Syst 29: 1227-1229.

47. Amer M, Mostafa FF, Tosson Z, Hegazi A (1996) Papillon-Lefevre syndrome associated with albinism. Clinical and immunological study. J Eur Acad Dermatol Venereol 6: 246-251.

48. Hewitt C, Wu CL, Hattab FN, Amin W, Ghaffar KA, et al. (2004) Coinheritance of two rare genodermatoses (Papillon-Lefévre syndrome and oculocutaneous albinism type 1) in two families: a genetic study. Br J Dermatol 151: 1261-1265.

49. Hattab FN, Amin WM (2005) Papillon-Lefévre syndrome with albinism: A review of the literature and report of 2 brothers. Oral Surg Oral Med Oral Pathol Oral Radiol Endod 100: 709-716.

50. Al Ghanam MA, Khawalde M (2012) Papillon-Lefèvre syndrome with albinism: A review of the literature and case report. OA Case Reports 1: 3.

51. Ashwani P, Swapna K, Rani SM, Reddy BSN (2010) Papillon-Lefevre syndrome with pseudoainhum. Indian Dermatol Online J 1: 33-35.

52. Gandhi V, Singal A, Mohanty S, Bhattacha SN, Baruah MC (1998) Papillon lefevre syndrome with mental retardation. Indian J Dermatol Venereol Lepro 64: 303-304

53. Mansur AT, Göktay F, DemirokN (2006) A case of Papillon-Lefevre syndrome associated with xanthogranulomatous pyelonephritis and hepatitis. J Dermato 33: $59-63$

54. Trattner A, David M, Sandbank M (1991) Papillon-Lefevre syndrome with acroosteolysis. J Am Acad Dermatol 24: 835-838.

55. Ganji K, Kumar D (2010) Papillon Lefevre Syndrome. IJDA 2: 217-219.

56. Haritha A, Jayakumar A (2011) Syndromes as they relate to periodontal disease. Periodontology 56: 65-86.

57. Inalöz HS, Harman M, Akdeniz S, Inalöz SS, Isik AG (2001) A typical familia Papillon-Lefèvre syndrome. J Eur Acad Dermatol Venereol 15: 48-50.

58. Soskolne WA, Stabholz A, Van Dyke TE, Hart TC, Meyle J (1996) Partia expression of the Papillon-Lefèvre syndrome in 2 unrelated families. $\mathrm{J}$ Clin Periodontol 23: 764-769.

59. Kothiwale SV, Mathur S (2008) Partial expression of Papillon-Lefèvre Syndrome CASE REPORT. Indian J Dent Res 19: 264-266.

60. Kamalpreet C, Amandeep C, Charanpreet J (2010) Late onset PapillonLefevre syndrome - A Case. BFUDJ 1: 102-104.

61. Reenesh M, Singh MM, Rath C, Mukherjee CM (2012) Papillon-Lefèvre syndrome associated with Aggressive periodontitis: A rare case report. Indian J Dent Adv 4: 956-958.

62. Fardal O, Drangsholt E, Olsen I (1998) Palmar plantar keratosis and unusual periodontal findings. Observations from a family of 4 members. J Clin Periodontol 25: 181-184

63. Pilger U, Hennies HC, Truschnegg A, Aberer E (2003) Late-onset PapillonLefe vre syndrome without alteration of the cathepsin $C$ gene. J Am Acad Dermatol 49: 240-243.

64. Kobayashi T, Sugiura K, Takeichi T, Akiyama M (2009) The novel CTSC homozygous nonsense mutation p.Lys $106 \mathrm{X}$ in a patient with Papillon-Lefèvre syndrome with all permanent teeth remaining at over 40 years of age. $\mathrm{Br} J$ Dermatol 169: 948-950. 
Citation: Dababneh RH, Bissada NF (2013) Syndromes that Include both Palmoplantar Keratoderma and Severe Periodontitis: a Review. Dentistry 4: 186. doi:10.4172/2161-1122.1000186

65. Noack B, Görgens H, Schacher B, Puklo M, Eickholz P, et al. (2008) Functional Cathepsin $\mathrm{C}$ mutations cause different Papillon-Lefévre syndrome phenotypes. $\mathrm{J}$ Clin Periodontol 35: 311-316.

66. Haim S, Munk J (1965) Keratosis palmo-plantariscongenita, with periodontosis, arachnodactyly and peculiar deformity of the terminal phalanges. $\mathrm{Br} \mathrm{J}$ Dermato 77: 42-54.

67. Hacham-Zadeh S, Schaap T, Cohen MM (1978) A genetic analysis of the Papillon-Lefe vre syndrome in a Jewish family from Cochin. Am J Med Genet 2: 153-157.

68. Hart TC, Hart PS, Michalec MD, Zhang Y, FiratliE, et al. (2000) Haim-Munk syndrome and Papillon-Lefèvre syndrome are allelic mutations in cathepsin C. J Med Genet 37: 88-94.

69. Dababneh RH, Jebrin SE, Khouri AT, Bissada NF (2013) Papillon-Lefevre or Haim-Munk Syndrome...? A Review and Report on Two Sisters in a Consanguineous Family (Submited for publication)

70. Shah KM, karagir A, Koppikar R, Adaki S (2013) Papillon Lefevre syndrome. BMJ Case Rep Published online.
71. Steijlen PM, Neumann HAM, der Kinderen DJ, Smeets DFCM, van der Kerkhof PCM, et al. (1994) Congenital atrichia, palmoplantar hyperkeratosis, mental retardation, and early loss of teeth in four siblings: A new syndrome? J Am Acad Dermatol 30: 893-898.

72. Van Steensel MA, Van Geel M, Steijlen PM (2002) New syndrome of hypotrichosis, striate palmoplantarkeratoderma, acro-osteolysis and periodontitis not due to mutations in cathepsin C. Br J Dermatol 147: 575-581.

73. Brun AM, van Steensel MA (2004) A third case of HOPP syndrome-confirmation of the phenotype. Br J Dermatol 150: 1032-1033.

74. Wiehe CB, Silver JG, Larjava HS (1996) Early-Onset Periodontitis Associated With Weary-Kindler Syndrome: A Case Report. J Periodontol 67: 1004-1010.

75. Kindler T (1954) Congenital poikiloderma with traumatic bulla formation and progressive cutaneous atrophy. $\mathrm{Br} \mathrm{J}$ Dermatol 66: 104-111.

76. Weary PE, Manley WE Graham GF (1971) Hereditary acrokeratoticpoikiloderma Arch Dermatol 103: 409-422.

77. Barber S, Day P, Judge M, Toole E, Fayle S (2012) Variant Carvajal syndrome with additional dental anomalies. Int J Paed Dent 22: 390-396. 